\title{
A Case for Cohabitative Security: The Philippine and Malaysian Experience
}

\author{
Michael I. Magcamit \\ College of Arts, Political Science, University of Canterbury, Private Bag 4800, Christchurch, New Zealand; \\ E-Mail: michael.magcamit@pg.canterbury.ac.nz; Tel.: +64 3642987 ext. 6053
}

Submitted: 13 February 2014 | In revised form: 14 June 2014 | Accepted: 22 June 2014 |

Published: 5 September 2014

\begin{abstract}
This article attempts to explore and analyse the evidence for cohabiting the human security concept into the national security frameworks of ASEAN countries. Using the Philippines and Malaysia as case studies, the article determines the extent to which public officials and policymakers have redefined and reenvisioned national security by incorporating non-traditional, people-centered elements of human security. The word 'cohabitation' refers to national governments' efforts to amalgamate statist and humanist dimensions of security when articulating and implementing their national security rhetoric and agenda. It argues that human security naturally complements state security, and vice versa. As such, human security and state security co-exist in a constructive manner that enhances the overall level of national security. In other words, they are mutually constitutive rather than mutually corrosive. Both cases underscore a two-pronged assumption. First, the meaning and provision of national security can neither be eloquently articulated nor completely substantiated without considerations for 'below the state' actors and issues. And second, the eminent status vis-à-vis power of the state in providing national security can neither be trivialized nor undermined.
\end{abstract}

Keywords: Cohabitative Security; Human Security; Malaysia; National Security; Philippines

\section{Introduction}

Twenty years after the official debut of human security in academic and policymaking circles in 1994, the concept continues to be a source of important debates directed at the progressive re-imagination of national security. In Southeast Asia, however, the concept has had very limited influence in the govern- ments' formulation and implementation of their respective national security rhetoric and agenda [1-3]. This is largely due to the conflicting views on what should be considered as a threat between the state and various non-state actors within these societies. At the heart of this conflict between statist and humanist advocates of national security is the shared belief among Southeast Asian leaders in the ASEAN Way [1-3].

(C) 2014 by the authors; licensee Librello, Switzerland. This open access article was published under a Creative Commons Attribution License (http://creativecommons.org/licenses/by/3.0/). 
For the region's top officials, the ASEAN Way is deemed the most appropriate style of diplomacy as it underlines the value of traditional notions of sovereignty and noninterference in conducting interstate relations [4]. While the Western method of diplomacy is driven by binding agreements through the adoption of legalistic procedures and formalistic solutions, the ASEAN approach operates through non-binding, invisible ground rules of informality, inclusivity and consensus [4]. Different labels have been used by various observers to describe the ASEAN Way such as 'organizational minimalism', 'soft regionalism', 'soft dialogue', and 'thin institutionalism' ([4] pp. 14-27). Such a preference for 'sports shirt diplomacy' over 'business shirt diplomacy' has naturally limited the practical application of human security in rethinking national security in the Southeast Asia ([4] pp. 14-27).

Against this backdrop, this article attempts to explore the evidence for the 'cohabitation' of human security concept within the national security framework of ASEAN countries in the twenty-first century. It specifically examines the Philippines and Malaysia's experiences with cohabiting state-centric and peoplecentered dimensions of national security. The word cohabitation in this context refers to the national government's attempt at amalgamating statist and humanist elements of security when articulating and executing its national security policies. The goal is to determine the extent to which policymakers have defined national security based on the cohabitation between state-centric and people-centered dimensions of national security. Cohabitative security, therefore, refers to the approach being employed by the Philippine and Malaysian governments in cohabiting human security into their national security frameworks.

The article argues that human security naturally complements state security, and vice versa. As such, human security and state security co-exist in a constructive manner that enhances the overall level of national security. On the one hand, state security does not automatically negate human security nor compete with individuals and communities; on the other, human security does not necessarily threaten state security nor compete against state actors and agencies. The reason for this is that human security and state security are mutually constitutive rather than mutually corrosive. This is particularly relevant in the context of the increasing, albeit gradual, recognition among ASEAN governments that human security is an essential dimension and necessary precondition for national stability and security. Such a scenario implies that the divisive dichotomy between these two security dimensions is hardly insurmountable. Ironically, it is the insecurity felt by individuals and states, rather than security that is transforming ASEAN's traditional normative terrain into a region cognisant of the value of cohabiting humanist and statist components of national security.
Moreover, by examining governments' efforts toward cohabitative security, the article argues that the inherent bias against states can be mitigated, enabling mutual trust to develop between the artificially divided state and non-state agents of national security. It highlights the areas where states, even if only to some extent, have practically contributed to the advancement of the human security agenda. This is not to defend or legitimize the shortcomings of states with respect to human security, but rather, to reopen the channel through which productive dialogues between governments and citizens can take place. The notion of cohabitative security does not provide a panacea to long-standing conceptual problems of national security. Nevertheless, it offers an alternative tool for reassessing governments' successes and failures in terms of incorporating individuals and societies in their respective national security discourses.

In advancing these arguments, the article examines the Philippines and Malaysia's experiences with cohabitative security and attempts to answer the following questions. First, who or what is the primary referent object in the Philippines and Malaysia's twenty-first century national rhetoric and agenda? Second, what are the main issues that threaten these primary security referent objects? And third, how do the Philippine and Malaysian governments, both past and present, address these threats? Have they been successful? Why or why not?

The article is divided into four sections. Section two examines the current composition of the Philippines' national security framework by identifying its main components and analyzing the most critical issues that threaten its primary security referent objectdevelopment space. It argues that against the backdrop of structural poverty and institutionalized inequality generated by a deeply-entrenched oligarchic system, the main referent object of Philippine national security is its diminishing development space. Development space refers specifically to the capacity of the Philippine government to independently and effectively pursue its economic development goals and objectives against these constraints. It analyses the limits to the Philippines' development-based national security framework, which in turn, undermine the effectiveness of the country's cohabitative national security, namely: (i) limits to democratization; and (ii) limits to Human Security Act (HSA).

Section three examines the present condition of Malaysia's national security framework by identifying its main components and analyzing the most critical issues that threaten its primary security referent object-diversity space. It argues that against the backdrop of a Bumiputra-centric political economy, developed and controlled by the UMNO-driven Barisan Nasional, the main referent object of Malaysian national security is its shrinking diversity space. Diversity space specifically refers to the capacity of all ethnic groups in Malaysia to participate freely in the country's 
political and economic affairs against these constraints. It analyses the limits to Malaysia's diversity-based national security framework, which in turn, undermine the effectiveness of the country's cohabitative national security, namely: (i) limits to ideational security apparatuses; and (ii) limits to material security apparatuses. The Philippines and Malaysia's primary security referent objects-development space and diversity space-represent the non-traditional, peoplecentred dimension of security as opposed to its traditional, state-centric dimension.

Finally, section four summarizes the main arguments presented based on the analysis of two empirical case studies. It concludes that despite the limitations of the Philippine and Malaysian governments in fully cohabiting the concept of human security into their respective national security frameworks, nonetheless, both countries have illustrated a concrete way of giving entitlement to non-traditional, people-centered elements of security as legitimate referent objects of national security. Both cases underscore a two-pronged hypothesis: (i) that the meaning and provision of national security can neither be eloquently articulated nor completely substantiated without considerations for 'below the state' actors and issues; and (ii)that the eminent status of the state in terms of power in providing national security can neither be trivialized nor undermined. Therefore, rather than downplaying a state-centric concept while highlighting a people-centred model, cohabitative security amalgamates statist and humanist views of national security. This is one way of resolving the 'entitled state/untitled human' dilemma in which the state is typically depicted as an antagonistic force impeding the pursuit of human security.

\section{Cohabiting Human Security into the Philippine's National Security Framework}

\subsection{The Philippines' 'Cohabitative' National Security}

The Philippines' 2011-2016 National Security Policy (hereafter, NSP) is a statement of principles designed for the strategic pursuit of the country's national interest defined in terms sovereignty and territorial integrity on the one hand, and people's well-being and institutions on the other [5]. Its primary objectives focus on balancing between 'guns and butter,' through more efficient allocation of the country's limited resources and effective prioritization of internal and external defense. It lays down a fairly comprehensive agenda which incorporates nonmilitary issues and threats encroaching upon the boundaries of the state. In the words of President Benigno Aquino III: 'our quest must not only focus on ensuring the stability of the State and the security of our nation...our ultimate goal must be the safety and well-being of our people' ([5] p. 1).

This holistic approach to national security underscores the need to rethink traditional security which made paramount the military protection of the state from external threats while disregarding issues generating human insecurities. It is part and parcel of the larger security sector transformation (SST) which represents a paradigm shift in security governance by acknowledging the blurring between internal and external threats [6]. The main thrust of the NSP is anchored in Aquino III's 'social contract' with the Filipinos, emphasizing commitments to transformational leadership through empowerment of the people and opportunities to enable the people to escape from the shackles of poverty ([5] p. 6). Aside from its customary role in fortifying the country's juridical borders, the NSP also aims to cultivate an environment conducive to human development, that is, a development-based NSP agenda. Thus, it brings together under one cohesive policy agenda a wide range of security issues, and balances these with its national peace and development perspectives.

The country's desire to serving as a committed and trustworthy member of the international community is, to a large extent, driven by the emergence of nontraditional security threats transcending national borders such as organized transnational crimes, terrorism and weapons of mass destruction, pandemics and infectious diseases, environmental degradation, and climate change to name a few [5]. In relation to this, the country also acknowledges the significant impact of globalization on its internal affairs. The NSP document, therefore, promotes the objective of forging strong political alliances with developed countries to further solidify its political presence in the international arena, and secure its economic and defense requirements [5]. The government believes that through diplomatic engagements, nations will cooperate rather than compete with each other [5].

In response to this changing security environment, the government has developed a national security model comprised of seven core elements that amplify national interests, including: socio-political stability, territorial integrity, economic solidarity, ecological balance, cultural cohesiveness, moral-spiritual consensus, and peace and harmony ([5] p. 3). These elements also take into consideration certain psychosocial aspects of national security including the people's customs and beliefs, as well as social characters and norms influencing perception of government-initiated policies and programmes ([5] p. 3). Hence, the government is very optimistic about the potential of its twenty-first century NSP agenda for achieving not only national peace and security, but, more importantly, development and prosperity. Working under a widely popular campaign slogan of Daang Matuwid (the high road), Aquino III's NSP strongly emphasizes the country's diminishing development space, articulating the issue as a national security threat that must be effectively secured ([5] p. 31):

"If the government is able to make good on the promise of taking the high road, the 'Ang Daang 
Matuwid', then it must be sure that the people are afforded every opportunity to pursue their individual dreams of a better quality of life-all under the consideration of national security where the welfare and well-being of the people are of primordial consideration."

From the government's perspective, addressing the country's long-standing problems of exacerbated poverty, widening inequality, and other socio-political maladies engendered by limited development space demands complementary policies such as robust public-private partnerships (PPP) on the one hand, and breaking patronage politics influencing decision making in government's programs and projects on the other [5].

Despite its development-based NSP agenda, the government still recognizes the importance of maintaining a credible external defense posture since globalization has not led to complete obsolescence of war as an alternative tool for settling disputes when diplomacy fails. Impaired by its present economic status, however, the country is struggling to assert and defend its position in international society. The government usually finds itself on the losing end when settling disputes with advanced countries, given its small player status in the global arena, both politically and economically. The debate between 'guns and butter' has to be settled in favour of 'butter' given the country's scarce resources. After all, as Aquino III has neatly put it, 'For Filipinos to feel this renewed sense of transformational leadership, they must also see and feel that the Government is for them, with them and serving them' ([5] p. 31).

\subsection{Limits to the Philippines' Development-based National Security}

Clearly, the Philippine government recognizes economic underdevelopment as a critical threat to national security. The important question that needs to be examined, however, is whether it is genuinely concerned about addressing the country's economic plight or is only paying lip service to the electorally-popular idea of people-centered national security. Despite the government's grand pronouncements about pursing equitable economic development to enhance national security, however, its security blueprint faces two limitations that put enormous challenge to such intention: (i) limits to democratization; and (ii) limits to human security act. The following subsections discuss these limits, which help explain the country's continuously shrinking diversity space, and subsequent failure to fully embed the notion of human security (defined in terms of economic security) into its national security framework.

\subsubsection{Limits to Democratization}

Based on historical analysis of politico-economic developments in the Philippines, the decision of the American colonial regime to transplant its own brand of representative democracy over an economic arrangement ruled by landed oligarchs enabled the latter to seize authoritative control over what should have been 'democratic' policymaking procedures and institutions [7]. Oligarchs in this context are 'actors who command and control massive concentrations of material resources that can be deployed to defend or enhance their personal wealth and exclusive social position' ([8] p. 6). Accordingly, an oligarch's ultimate goal 'is to secure, maintain, and retain his or her position of extreme wealth and power against all manner of threats' ([8] p. 6). In Aristotle's formulation, democracy is defined as the rule by the poor majority, whereas oligarchy is the rule of the wealthy few [8]. However, democracy and oligarchy 'can coexist indefinitely as long as the unpropertied lower classes do not use their expanded political participation to encroach upon the material power and prerogatives of the wealthiest' ([8] p. 11). In other words, the two systems are compatible for as long as the two realms of power do not clash. So while oligarchy 'rests on the concentration of material power', democracy 'rests on the dispersion of nonmaterial power' ([8] p. 11).

In the case of the Philippines, US officials left aside policies that could have transformed its political system into a more level playing field. The country's domestic political space was insulated from revisionist agendas espoused by various social factions springing from a broad base of political capital [7]. In stark contrast to the Philippine experience, the Japanese consciously shut down the elite's access to political power when they took over Korea, creating a very different political climate for the latter state [9]. The Philippines' government's capacity for independent action, therefore, is effectively curtailed by oligarchic groups attempting to amass public power to preserve vested interests [10-12]. Further, the 'redemocratization' process that took place immediately after the collapse of Ferdinand Marcos' dictatorship only resulted in the reinstallation of the pre-Marcos political order. This led to the re-emergence of elite ascendancy over domestic economy-the sine qua non for Philippine economic underdevelopment ([7] p. 49). Despite the introduction of various democratic institutional reforms, oligarchic forces are still able to manipulate and saturate the bureaucracy, impairing Philippine polity.

The question therefore is, why and how does oligarchic power overcome state power? Throughout Philippine history, several influential families owning huge corporations and vast lands have ruled over the bureaucracy, exploiting the country's public goods and resources that continue to fuel institutionalized corruption. Several infamous terms such as 'anarchy of families', 'booty capitalism', and 'cacique democracy' ([7] p. 50) have been used to describe the country's 
pitiful politico-economic construct. The conspicuous incapacity of the government to 'immunize' itself from oligarch manipulation has been at the crux of economic underdevelopment [13-15]. This unique political climate enables the 'top $5.5 \%$ landowning clans to own $44 \%$ of arable land and as few as 100 families control all electoral positions on a national level' ([16] p. 13). It is a side-effect of the strategy employed by the US regime to consolidate power throughout the archipelago that the landed elite were allowed to further expand their economic power by means political appointments [7].

When put together, Filipinos' distinctive concepts of family and land give rise to the so-called 'patron-client relationships' which can be used to explain Philippine political economy [17-18]. The patronage system which emphasizes the Filipino culture of 'giving for gratitude' and 'labour for loyalty' explains the existence of an omnipotent elite dominating the country's economy cum politics [19]. In this scenario, both the peasants' and the labourers' interests feed into the landlords' preferences through material and/or personal transactions via colloquial networks [20].

Hence, when the US colonial regime decided to establish political offices for electoral contest, the elite clans consolidated their power in order to give birth to national oligarchy instead of a national government (Anderson 1998). With this newfound power, the ruling elite are now in the position to thwart policies that favour both enemies and competitors. This system of politicking gave rise to what the Filipinos call, trapos or 'dirty' traditional politicians [21-23]. These trapos are responsible for the presence of 'reverse accountability' in Philippine politics by holding individual voters accountable for electing their respective patrons to power in exchange for favours provided in the past or those promised once said politician elected ([7] p. 55). The provision of favours, however, does not always translate to actual votes. In such cases, intimidation and aggression are often employed by political players owning private armies to ensure the delivery of paid votes [24]. The alternate use of benefits and violence for preserving political power and control essentially transforms traditional political aristocracy into some type of warlords [25]. In can be inferred, therefore, that the voters' support for their patrons is largely a function of the latter's 'own interests, rewards for loyalty, and the fear of vengeance' ([26] p. 260).

The nature of Philippine political-economy is referred to as a neo-patrimonial system [10]. A patrimonial state that allows oligarch relations and interests to dominate bureaucratic systems creates a hunting ground for the unrestricted accumulation of personal wealth [27]. Since the rent-seekers emerging from this bureaucratic capitalist system are able to control formal state structures from the outside, the term becomes 'neo-patrimonial' or 'booty capitalism' ([10] pp. 18-21).
The overwhelming oligarchic influence has significantly contributed to the deterioration of economic development in the Philippines since gaining independence from the United States in 1946 [28]. Even the implementations of disastrous economic policies advanced by top government officials were eventually manipulated to protect the interests of Filipino oligarchs. Philippine underdevelopment, therefore, is not just a matter of constantly choosing the wrong policies, but rather the result of conscious efforts by rent-seekers to maintain them for the continuous exploitation of state mechanisms and resources.

A perfect illustration of a 'wrong' policy selection was the espousal of import substitution industrialization (ISI) as the country's primary trade strategy after its official independence from the US [29-30]. In contrast to East Asian countries that launched an export-oriented strategy leading to annual per capita GDP growth of $6 \%$, the Philippines chose to implement ISI and became the worst performing economy in the Eastern half [31]. While the promotion of ISI may indeed have been an honest mistake on the part of Filipino technocrats, the oligarchs' indifference toward the correction of this mistake nevertheless underlined the unintended benefits it created with respect to the their interests. Despite the exacerbated balance of trade and payments problems created by ISI, this policy was maintained not for its effectiveness in resolving the crisis but for its role in opening a wider space for 'oligarch predation' ([7] p. 57). This confounding relationship between local oligarchs and the Philippine government is often referred to as 'rent capitalism' wherein rents are created by the latter to provide the former with a synthetic advantage by imposing restrictions on the free flow of foreign goods and services into the market [32].

U.S. Governor-general William Howard Taft's 'policy of attraction'-originally designed to entice the landlord class into collaboration with the Americans rather than pursuing revolutionary struggles-transformed the economic elite of the Spanish-colonial era into a political-economic elite that continues to dominate domestic politics today ([33] p. 142). And since representative institutions had already emerged prior to the development of a strong republic, patronageinfested political parties had single-handedly squashed government reforms that threatened to curb their power. In the Philippine context, political parties are 'convenient vehicles of patronage that can be set up, merged with others, split, reconstituted, regurgitated, resurrected, renamed, repackaged, recycled, refurbished, buffed up or flushed down the toilet anytime' ([34] pp. 4-5). This resulted to further marginalization of the masses who were unable to challenge the deeply-entrenched national oligarchy.

The palpable failure of American colonial regime to renovate the foundations of domestic political power vis-à-vis the imposition of its own brand of representative democracy on top of an unjust economic 
edifice, created an environment conducive to oligarch predation by exploiting state institutions and manipulating economic policy formulation [7]. The Philippine government has continued to operate within this context from one administration to another since the country's formal independence. Therefore, implanting a new constitutional framework that replicated a preMartial Law system within a relatively unchanged economic arrangement would be futile and counterintuitive to the prospect of change. In short, neither regime change nor democratization helped in mitigating the oligarch's influence over state affairs, particularly in decisions involving the national economy. As a consequence, a strongly developed Philippine republic is yet to emerge [7].

\subsubsection{Limits to Human Security Act}

The post-1986 People Power Revolution paved the way for rethinking national security as the security of the people. The perceived divide between people and state is artificial as they both comprise the nationstate [35]. Although the government is gradually progressing toward the integration of human security in its formulation of national security, the environment within which such policy amendments are being configured remains largely unstable and multifaceted. Advancements made toward a humanist view of security strategy are in danger of being undermined by institutional mechanisms with inadequate capacity to effectively combat contemporary security problems. And while Filipino policymakers acknowledge the severity of nontraditional threats trespassing on the country's supposedly sovereign boundaries, the term human security is still nowhere to be found in its official NSP document. This implies that the normative foundations of human security are not consistently implanted when designing a definitive NSP agenda despite references being made regarding the protection of grassroots civil societies [35].

A good example supporting this argument is the passage of the Human Security Act of the Philippines or the Republic Act No. 9372 in February 2007. This Act defined human security as an 'act to secure the state and our people from terrorism' defined as 'sowing and creating conditions of widespread and extraordinary fear and panic among the populace, in order to coerce the government to give in to an unlawful demand' [36]. In short, the country's HSA is both too narrow and too broad at the same time. On the one hand, it frames human security within the narrow context of terrorism which contradicts the government's holistic approach to national security, as well as the UNDP's comprehensive interpretation of human security [37]. On the other hand, it precludes the fundamental aspects of a terrorist act in favour of broad and vague expressions such as 'widespread and extraordinary fear and panic among the populace' or 'unlawful demand' which also run in contrast to the definition proposed by the UN High Level Panel on Threats, Challenges and Change [38].

While the official discourse of HSA highlights its importance for giving the government's all-out war against terror legal teeth by complementing AFP's strategic operations, however, law enforcement agencies seem to be uncomfortable with its implementation [39]. Such contradiction underlies reservations toward the Act, given its use of misleading semantics. Moreover, human rights groups have strongly opposed the legislation of the HSA arguing that it constitutes the building blocks of martial law. The rights that are at risk of being violated include freedom of expression, association, speech, movement, and due process, among others [40]. The accountability of the Anti-Terrorism Council for human rights violations while carrying out its mandate of fighting against terrorism is not specifically addressed in the said Act, blurring the line between Judiciary and Executive roles [40].

Supporters of the anti-terrorism legislation, on the other hand, point to Section 2 of the Act which highlights the safeguard mechanisms for protecting human rights by upholding basic rights and fundamental liberties as enshrined in the Constitution. They argue that the HSA is crucial for strengthening the country's democratic ideals since 'unlike the secrecy surrounding the pre-HSA extrajudicial killings, the new law makes the prosecution of terrorists a transparent matter that proceeds under the supervision of the Philippine judiciary' ([41] pp. 215-216). Despite such contextualization, the inefficiencies of the country's criminal justice system have not been properly addressed [42]. Understandably, several international organizations, most notably the International Federation for Human Rights and Human Rights Watch, are sceptical about the effectiveness of these safeguards, given the government's bad record for policy implementation, and they argue that what the Philippines really needs is not a new and dangerously broad counterterrorism law, but better efforts to make its current justice system work [43].

This age-old dichotomy between the ineffectiveness of the law and the inefficiency of the system is underlined in the report published by the National Council of Churches in the Philippines, which asked, 'How can the State-which stands criticized for tolerating, if not authorizing the gross and systematic violations of human rights - guarantee that, in implementing the HSA, the people's civil and political rights are not trampled upon' ([40] pp. 168-169)? As such, various segments of civil society including the academia and NGOs share the view that RA9372 is in violation of the Philippine Constitution by purporting information designed to mislead the people [40].

Overall, these two limits have significantly undermined the Philippine government's efforts at effectively cohabiting human security (defined in terms of economic security) into its national security 
framework. At the root of this insecurity is a deeplyentrenched patronage system controlled by powerful Filipino oligarchy. The pervasiveness of this politicoeconomic arrangement has resulted to structural poverty and institutionalized inequality that undermines the Philippines' supposedly people-centred national security model. Neoliberal economic policies intended to improve development have been cunningly exploited by oligarchic forces to their uncontested advantage. By systematically obstructing social-equalizing measures that curtail oligarchic wealth, 'national' prosperity is permanently entrapped within the elite strata of the society. The omnipresence of neo-patrimonial culture in the Philippines reinforces a 'bipolar' society wherein a few families enjoy the abundance of wealth at the expense of the majority. Despite the Philippines' cohabitative national security framework underlining equitable and inclusive economic development, the limits to democratization vis-à-vis its Human Security Act, have significantly undermined this end goal.

\section{Cohabiting Human Security into Malaysia's National Security Framework}

\subsection{Malaysia's 'Cohabitave' National Security}

Malaysia's national security rhetoric and agenda are a reflection of the government's struggle to transform a former British colonial territory into one cohesive and united nation. Accordingly, Malaysia adopts a fairly comprehensive approach in defining national security by weaving together its military, political, economic, social, cultural, and psychological components [44]. Several material and ideational factors influence Malaysia's conception of national security, including: geography and history; multi-ethnic identity and religious plurality; an aspiration for national unity and integration; and a dream of becoming a developed country and a model Islamic nation [45-46].

As such, Malaysia's national security encompasses both internal and external dimensions. On the one hand, the domestic security being derived from internal peace, law, and order is crucial to the fulfilment of basic needs and demands of its pluralistic society [4546]. The presence of internal stability and harmony underpin Malaysia's pursuit of national development and progress. Hence, the passage and enactment of legislation considered draconian in some liberal democratic states is deemed necessary by the Malaysian government in order to control its ethnically-diverse population [46-48]. On the other hand, external security focuses on wide-ranging transnational threats engendered by regional and global events including terrorism, maritime piracy, drug cartels, illegal migrant workers, and human trafficking, to name a few [4951]. Malaysia's pursuit of national security, therefore, implies the notion of strategic survival, both inside and outside its sovereign boundaries.

The conception of Malaysian national security has been largely inspired by the Emergency period between the years 1948 and 1960 [45,52-55]. This period saw the Malayan forces, backed by their British colonizers, fight against the Malayan National Liberation Army (MNLA), a group of Communist insurgents who claimed to be promoting a new democratic socialist Malaya $[45,46,52]$. In response, the coalition launched its 'hearts and minds' campaign to weaken the social appeal of Communist propaganda and earn the loyalty of those sympathetic to them $[45,48$, 52,56-57]. This proved to be an effective component of the coalition's anti-Communist strategy as it led to the establishment of a new constitution singed between the United Malays National Organization (UMNO) and the Malaysian Chinese Association (MCA) in 1957 [45-46]. It is worth noting that both signatories are member parties of the ruling BN coalition.

The new constitution recognizes the legality of special preferences and privileged positions being provided to the Malays [45,48,52-58]. Islam has been formally elected as the state religion, while Malay was made as the country's official language. Moreover, the new constitution has granted a fixed quota of posts in the civil service to Malays in addition to their guaranteed traditional land rights. In exchange for accepting these terms under the Constitution, the Chinese have been offered extended rights of citizenship [45-46,59]. As stated in Article 153 of the Malaysian Constitution:

It shall be the responsibility of the Yang diPertuan Agong (King of Malaysia) to safeguard the special position of the Malays and natives of any of the States of Sabah and Sarawak and the legitimate interests of other communities in accordance with the provisions of this Article [60].

Thus, the Constitution provides strong legal basis for the provision of exclusive rights and privileges to Malays, locally known as the Bumiputras (literally, sons of the soil) which are not extended to other ethnicities thriving in Malaysia, particularly the Chinese and Indian-Malaysians. Notwithstanding Malays' continued political supremacy and a considerably enhanced economic status, Article 153 remains entrenched in the Constitution. The application of the Malaysian Constitution legitimizes Malay interests even at the expense of all other Malaysian ethnic groups.

The Emergency period served as a sine qua non for legitimizing a national security framework that is both operationally despotic and ideologically centered on addressing the root causes of threats. Malaysia's national security is essentially based on material and ideational constructs designed to secure its ruling dynastic coalition-the Barisan Nasional (BN)-rather than the diversity space necessary for accommodating the political and economic needs of its multiethnic population. In fact, the $\mathrm{BN}$ defines itself as a confederation of political parties that subscribe to the objectives of the coalition, as opposed to the objec- 
tives of Malaysia's national interest [61].

Combining ideological constructs with a coercive apparatus has been the traditional approach to developing Malaysia's national security rhetoric and agenda since the period of Emergency $[46,52,54-55$, 62]. Such an approach is designed to secure the BN by suppressing the growth of unorthodox ideas and concepts, while justifying the supremacy of values being cultivated by the ruling coalition. Together, coercive and ideological instruments have played a crucial role in Malaysia's national security, which made paramount the implicit protection of the Malay-dominated coalition at the expense of its diversity space.

\subsection{Limits to Malaysia's Diversity-based National Security}

In doing so, the UMNO-led BN coalition has vigilantly upheld a paradoxical security framework propelled by its 'hearts and minds' slogan exercised through coercive and repressive legislation [48, 62-63]. Such a paradox presents two critical limits to Malaysia's diversity space that is pivotal to the country's cohabitative national security, namely: (i) limits to ideological security apparatuses, and (ii) limits to material security apparatus. The interplay between these factors substantially undermines the country's capacity for independently formulating and executing political and economic policies vital to its national security. The succeeding subsections discuss these limits which help explain the country's continuously shrinking diversity space, and therefore, its failure at fully embedding the notion of human security (defined in terms of ethnic security) within its national security framework.

\subsubsection{Limits to the Ideological Security Apparatus}

A central task of the BN's security ideology is the regulation and control of alternative channels for discussing nonconforming opinions [48,62]. A variety of ideological constructs have been put in place to legitimize the suppression of local political opponents and critics, thereby protecting the prevailing Malaydominated status quo. As Downs ([64] p. 96) argues, these nonmaterial forces represent 'a verbal image of the good society and of the chief means of constructing such a society.' In other words, the government systematically regulates the employment of ideologies to promote and preserve the security of the BN coalition, pursued under the pretext of safeguarding the constitutionality of specific Malay rights and privileges that do not apply other ethnic groups.

The coalition's security ideologies serve a two-level function: first, restricting the space available for alternative ideas that question the $\mathrm{BN}$; and second, legitimizing the passage and enactment of coercive instruments vis-à-vis the coalition that exercises them $[48,63]$. In doing so, they help in securing the preeminent status of the coalition against threats coming from various oppositional groups. The fluidity of ideas, however, implies that the coalition's security ideologies are neither permanent nor fixed but are contingent on specific political and social contexts of the time $(48,62]$. Hence, there is no overarching idea that dominates Malaysia's security rhetoric. Nevertheless, there is an underlying goal that binds these security ideologies together, that is, winning the hearts and minds of societal actors that threaten Malaysian national security defined in terms of $\mathrm{BN}$ security.

These coalition-enhancing ideational forces create a 'cloak for shabby motives and appearances' by legitimizing and giving meaning to its conduct ([65] p. 314). They act as political tools for securing the coalition's hegemony, rather than being mere reflections of the country's national aspirations. The uncertainty and complexity of Malaysian politics in the twenty-first century transforms these ideological constructs into electoral 'chips' necessary for continued survival of the coalition $[48,53,62-63,66-68]$. Accordingly, the ideational components underpinning Malaysia's national security framework are naturally bent to quash counter-narratives, thereby further shrinking the country's diversity space.

Islam plays a pivotal role in the hearts and minds campaign of the coalition. As a Muslim-dominated federal constitutional monarchy, Malaysia's national security becomes a function of its state-configured Islamic ideology $[48,63,69-71]$. Its goal is to cement the country's role as a worthy leader of the Muslim world by projecting an image of moderation and tolerance $[48,62-63]$. Islam must be the people's way of life and the coalition's brand of leadership. It is the very 'visible hand' that runs and controls Malaysia's internal and external affairs, and dictates what the objectives of national security will be. Crafting the country's national security rhetoric and agenda based on the underlying goal of securing the coalition becomes the paramount concern of the ruling $B N$ political elites, particularly for those comprising the United Malays National Organisation (UMNO) party [48,62-63].

On the one hand, Mahathir's security ideology represents a two-faced Malaysian national security framework by endorsing a non-violent and non-forcible Islamic rhetoric at the international scene, while encouraging coercive and aggressive policies in implementing these teachings at the domestic sphere on the other $[48,59,63]$. Such an approach to national security effectively aids in the legitimization of the coalition's domestic security machinery which means the perpetuation of the Malay-dominated BN coalition, and therefore, the diminution of Malaysia's diversity space.

At the international level, the Mahathir regime has portrayed Malaysia as the 'model Islamic state' of the post-9/11 world [48,51,55,62-63]. The former PM argued that its government had been successful in fighting terrorism domestically by adding ideological 
'sweeteners' to its coercive policies [51,55,62]. Such a claim is typically made in the context of the Emergency, where the defeat of communism is largely viewed as a result of its hearts and minds ideology, emphasizing a moderate and tolerant Islam [45$46,52,54,62]$.

At the domestic level, however, the opposite is observed. Mahathir's state-sponsored Islam has been propagated with the help of strong coercive legislation, particularly the Internal Security Act (ISA) of 1960 and its replacement, the Security Offences Special Measures Act (SOSMA) of 2012 [48,54,56, $59,63,72]$. This highlights underlying contradictions within Mahathir's ideational panorama-conquering the hearts and minds of a fearful population through the forced imposition of a coalition-made Islam. The implicit goal of eliminating counter-narratives to BN's vision of Malaysian nation-building has been pursued under the banner of counterterrorism $(48,63)$.

On the other hand, Badawi's security doctrine which he called Islam Hadhari (Civilizational Islam) still reflects Mahathir's aim at securing the coalition, rather than the diversity of its multi-ethnic population $[48,63,73-74]$. Substance-wise, Islam Hadhari has no significant difference from Mahathir's Asian values [75]. In terms of form, however, Abdullah's ideology takes Mahathir's notion of the 'model Islamic state' to a higher level, by developing a comprehensive doctrine embracing Muslim and non-Muslim audiences alike, both at home and abroad [48,63]. In other words, Malaysia's signature Islam has been transformed into an exportable commodity that reinforces the legitimacy of the $\mathrm{BN}$ coalition beyond the country's borders $[48,73]$.

The terms that have been used to develop Islam Hadhari were fairly 'universal', and as such can be applied to different contexts. Badawi's ideology represents a shift toward understanding the contemporary era within the purview of Islam [73]. It is the form, rather than substance that made Islam Hadhari an appealing ideological construct $[48,63]$. By utilizing charismatic Islamic terminology, Badawi has succeeded in reigniting the coalition's unpopular security ideology (Liow 2005). Badawi's main thrust is to recalibrate Islam as a progressive religion that values individual and communal development [76]. For instance, the fourth, fifth, and sixth principles highlight Islam Hadhari's economic undertones which reflect Badawi's promotion of Islam as a religion for development $[48,51,63,57,77-78]$. By restoring the sense of moderation toward the practice of Islam, Badawi had hoped that non-Muslim Malaysians would feel embraced by the regime [69].

At the international level, Badawi attempted to export Islam Hadhari to both Muslim and non-Muslim countries. The idea is to cement Malaysia's role as a model nation and leader of the Muslim world by manufacturing it as a development model based on a state-authorized version of Islam $[48,63]$. However, at the domestic level, the operationalization of Badawi's doctrines is questionable at best. It is not clear whether Islam Hadhari represents genuine efforts toward a progressive interpretation of Islamic thinking, or merely a strategy for securing Malaysian votes by not openly marginalizing its non-Malay and non-Muslim population $[69,76]$.

The coalition has utilized its ideological machinery in justifying the coercive measures undertaken during a series of crackdowns against 'deviant' sects such as the Tarikat Samaniah Ibrahim Bonjol in 2004, and Terengganu or Sky Kingdom in 2005 [79-81]. In 2004, seventy members of the Muslim sect Tarikat Samaniah Ibrahim Bonjol were arrested in Selangor by Islamic religious authorities [79-81]. The government claimed that the sect treated the Qur'an as a historical text, which resulted to its 'casual' attitude toward prayer and marriage. In the aftermath of these arrests, Malaysian chief executive, Khir Toyo announced his plan to vanquish some sixty divergent sects operating in Selangor [79-81]. In 2005, another religious sect in Terengganu known as Sky Kingdom was also shut down by the Department of Islamic Development [79]. The government claimed that the movement was propagating documents that countered Islamic teachings. Its leader, Ayah Pin was presented to the public as threat to national security by espousing alternative views on religion and lifestyle that differ from those provided by the government. In doing so, Aya Pin was not only jeopardizing the country's official religion but also destabilizing the political status quo [80].

The government has portrayed these religious entities as threats to Malaysia's national security by espousing alternative views of Islam, and adopting a lifestyle different from the ones endorsed by the $\mathrm{BN}$ coalition. However, Sky Kingdom's 'threats' to national security were ideational rather than material in nature. These events offer a glimpse to the condition of diversity space in Malaysia despite its multiethnic, multireligious society. These events highlight $\mathrm{Ma}-$ laysia's unsecured diversity space amid a multiethnic, multireligious society, which in turn, undermines the country's national security.

Islam Hadhari has also provided the government an effective ideological apparatus for stifling its political rival, the Pan-Malaysian Islamic Party (PAS). Badawi has likened PAS' brand of Islam to a trap that must be exposed to prevent Malay Muslims from being ensnared $[48,74]$. Under Islam Hadhari, the PAS is faced with a lose-lose situation: either to comply with a BN-sponsored Islam and operate within this limited context or reject this model and become an enemy of the state $[48,55,63,76]$. Either way, the ideological terrain within which PAS can manoeuvre is significantly diminished. Needless to say, Islam Hadhari has further enhanced the government's monopolistic control over the organization and facilitation of Islam. Divergent sects operating beyond the provisions and boundaries 
set by the coalition are more easily detected and trounced. Hence, Islam Hadhari becomes an extension of the implicit campaign against the expansion of the diversity space critical for Malaysia's pluralistic society.

\subsubsection{Limits to the Material Security Apparatus}

The government's ideational security constructs are complemented by a material security apparatus. This involves are coercive laws designed to secure the status-quo by removing all material and/or ideational challenges to its legitimacy [45-46,48,53-55,58$59,63,67,82]$. A primary example is the recently repealed Internal Security Act (ISA) passed by PM Abdul Rahman in 1960 [83]. The ISA served as a preventive detention law which enabled the arrests of individuals without trial and criminal charges under limited, legally defined circumstances for sixty days. Moreover, the Act also allowed the extension of this detention period for up to two years upon the discretion of the Home Minister with minimal judicial review [83]. As stated in Section 73 of the Act, 'any police officer may arrest and detain without warrant any person who has acted or is about to act or is likely to act in any manner prejudicial to the security of Malaysia or any part thereof' [83].

The ISA is further complemented by the Sedition Act, revised in 1971 by Malaysia's second PM Tun Abdul Razak which made any questioning of Malayan paramountcy an act of treason. The Act prohibits virtually all activities with 'seditious tendency', resulting to disaffection and hostility toward the government or communal ill will [84]. Despite initial controversies, the coalition has skilfully justified the presence of ISA and Sedition Act as necessary legislation for ensuring Malaysia's national security [45-46,52].Such laws are deemed to be particularly relevant in the context of the post-9/11 world order, where they serve as effective counterterrorism measures akin to the Patriot Act of the US, and the Anti-Terrorism Act of the UK.

In recent years, however, opposition to the ISA has grown considerably. Critics have argued that the Act was passed to stifle what should have been legitimate political oppositions under a well-functioning democratic society and as such had been compared to internal pre-emptive strike, given its preventive nature [53-54]. For example, during the 1987 Operasi Lalang (Weeding Operation), 106 people were arrested without proper charges under the ISA. Most of the detainees were members of the opposition party and various social activist groups. The coalition issued a White Paper explaining the arrests, stating that various groups which had played up sensitive issues and thus created racial tension in the country had exploited the government's liberal and tolerant attitude [54-55,85-86].

One of the most significant outcomes of this struggle was the introduction of section $8 \mathrm{~B}$ of the ISA which blocked judicial review of ISA detentions including those brought as habeas corpus petitions [87-88]. In 2001, this section of the ISA was used to detain members of the People's Justice Party (PJP) dubbed as the 'Reformasi or KeADILan 10' [87-88]. The detainees, led by Anwar Ibrahim's wife, Wan Azizah Ismail pressed vocally for his release, Ibrahim had been convicted of misuse of power and sodomy in trials, which according to Human Rights Watch, were marred by coerced confessions of key witnesses [8788]. Prior to his imprisonment, Anwar was leading rallies across Malaysia in support of his newlyformed reformasi movement, preaching to vast crowds in favour of far-reaching social, political, and economic reforms $[45,54-55,86]$. In response, Mahathir's side claimed that the arrested activists were planning violent protests to overthrow the government and were attempting to procure dangerous weapons and explosives [87-88]. Yet despite the serious nature of these charges, the government failed to produce any credible evidence to support its claim.

These abuses drove oppositionist groups, human rights activists, and other civil society advocates to mobilize large-scale protests against the ISA, portrayed as unnecessary draconian law that does not bode well for Malaysia's vision of progressing toward 'developed nation' status [87-88]. The popularity of these movements, along with the resurgence of a stronger opposition after the 2008 General Election, played a crucial role in PM Najib's decision to repeal the Act. In 2012, the Security Offences (Special Measures) Act or SOSMA has officially replaced the ISA [89]. The new Act is envisioned 'to provide for special measures relating to security offences for the purpose of maintaining public order and security and for connected matters.'

In contrast to ISA, the new law requires the filing of charges based on credible evidence against detainees after twenty-eight days [89]. Thus, the burden to produce reliable proof within a specified time frame is shifted to the government's law enforcement and intelligence agencies responsible for combating terrorist activities. However, SOSMA is also being criticized from both sides. On the one hand, anti-terrorist groups argue that the requirement to bring charges within twenty-eight days under SOSMA weakens Malaysia's capacity to pre-emptively contain terrorist threats [90]. On the other, human rights groups criticise SOSMA for allowing police to authorise communication intercepts and permitting prosecutors to present evidence without disclosing sources. Moreover, acquitted suspects in the midst of an appeal may still be detained in prison or tethered to a monitoring device until the appeal is formally settled [90].

Overall, these two limits have significantly undermined the Malaysian government's efforts to effectively cohabit human security (defined in terms of ethnic security) into its national security framework. The BN's ideational and material security apparatuses 
ensure the preservation of a Malay-dominated status quo. In the process, the BN has become synonymous with the Malaysian nation-state. The noble objective of protecting Malays' interests is equated to the venal objective of preserving the BN's political supremacy, pursued under the banner of securing Malaysia's shrinking diversity space. In pursuing its Bumiputraoriented social vision, the government has utilized trade liberalization, along with complementary neoliberal economic policies, but often at the expense other Malaysian ethnic communities. In other words, they have been fervently pursued to reinforce and safeguard a Malay-imagined society. As long as the constitutional frameworks that legitimize a Bumiputracentric Malaysian nation-state are sustained, deethnicizing the country's politico-economic and sociocultural arrangements remains highly implausible. Thus, Malaysia's national security is, for better or worse, developed around Malay ethnic identity.

\section{Conclusion}

This article has critically examined the Philippines and Malaysia's experiences with cohabiting the human security concept into their respective national security frameworks. It argued that while on the one hand, the Philippines' primary security referent object is its shrinking development space amid a deeply-entrenched patronage system controlled by a powerful Filipino oligarchy; on the other, Malaysia's main security referent object is its contracting diversity space amid a Bumiputra-centric political economy, developed and controlled by the perpetually ruling $\mathrm{BN}$ coalition. Both the Philippines and Malaysia's primary security referent objects-development space and diversity spacerepresent the non-traditional, people-centred dimension of national security rather than its traditional, statecentric dimension.

A variety of limits have severely undermined the two countries' efforts at cohabiting human security into their respective national security frameworks. In the case of the Philippines, the limits of its democratization and its Human Security Acts have produced an enormous challenge to securing its development space, defined in terms of economic security. Whereas in the case of Malaysia, the limits to ideological and material security apparatus have presented significant constraints in securing its diversity space, defined in terms of ethnic security.

These limits have contributed to the country's lacklustre experience with cohabitative security. Nevertheless, both cases have illustrated a concrete way of giving entitlement to non-traditional, peoplecentered elements of security as legitimate referent objects of a national security framework. The Philippine and Malaysian experiences underscores a two-pronged assumption: first, the meaning and provision of national security can neither be eloquently articulated nor completely substantiated without consideration of 'below the state' actors and issues; and second, the eminent status of the state vis-à-vis power in providing national security can neither be trivialized nor undermined.

Hence, instead of downplaying a state-centric concept while highlighting a people-centred model, cohabitative security amalgamates statist and humanist views of national security. This is one approach to resolving the 'entitled state versus untitled human' dilemma in which the state is ordinarily depicted as an antagonistic force obstructing the quest for human security.

This invisible yet concrete divide between states and individuals vis-à-vis communities, creates a distorted view that the state does not acknowledge the multidimensionality of national security in the modernday era. Thus, despite claims being made by state actors with regard to their revised national security rhetoric and agenda, non-state actors continue to view national security as a purely militaristic object bereft of human sensibility. On the one hand, the state claims to have created a novel national security vision protecting human security. But on the other hand, citizens and communities equate national security to the anachronistic pursuit of sovereignty and territorial boundaries.

The employment of cohabitative security means that state security and human security become mutually constitutive and reinforce dimensions of national security. A shift in the government's perception of state security can have a corresponding impact on individuals and communities' collective perception of human security, and vice versa. Therefore, this allows the state to have a more positive and nurturing image in the security narrative. It veers away from the innate tendency to portray the state as a completely distinct security domain that must be temporarily de-emphasized and/or unaccounted for when advancing human security objectives.

In doing so, it 'unvilifies' the role of the state in pursuing a human security rhetoric and agenda. Instead of being diametrically opposed, the cohabitative security approach shows that state security complements human security, and vice versa. To some extent, the invisible divide between the 'high politics' of the states and the 'low politics' of the people and communities is bridged, enabling state actors to realize the multidimensionality of national security in the twenty-first century. A more collective understanding of national security shared by governments and citizens is therefore realized. 


\section{References}

[1] Nishikawa Y. Human Security in Southeast Asia: Viable Solution or Empty Slogan? Security Dialogue. 2009;40(2):213-236.

[2] Nishikawa Y. The ASEAN Way and Asian Regional Security. Politics and Policy. 2007;35(1):42-56.

[3] Caballero-Anthony M. Revisioning Human Security in Southeast Asia. Asian Perspective. 2004;28(3):155-189.

[4] Capie D, Evans P. The Asia-Pacific Security Lexicon. $2^{\text {nd }}$ edition. Singapore: Institute of Southeast Asian Studies; 2002.

[5] Republic of the Philippines. National Security Policy 2011-2016: Securing the Gains from Democracy. Quezon City, Philippines: National Security Adviser; 2010. Available from: http://www.gov.ph/ 2011/08/18/national-security-policy-2011-2016/.

[6] Brochert H, Oriesk D. Security Sector Transformation: Why New Risk Demands for New Kind of Security Governance. Washington, DC, USA: Booz Allen; 2004.

[7] Manacsa R, Tan A. Strong Republic Sidetracked: Oligarch Dynamics, Democratization, and Economic Development in the Philippines. Korea Observer. 2012;43(1):47-87.

[8] Winters J. Oligarchy. Cambridge, UK: Cambridge University Press; 2011.

[9] Hutchcrot P, Rocamora J. Strong Demands and Weak Institutions: Addressing the Democratic Deficit in the Philippines. Journal of East Asian Studies. 2003;3(2003):259-292.

[10] Hutchcroft P. Booty Capitalism: The Politics of Banking in the Philippines. Quezon City, Philippines: Ateneo de Manila University Press; 1998.

[11] McCoy A. An Anarchy of Families. Quezon City, Philippines: Ateneo de Manila University Press; 1994.

[12] Villacorta W. The Curse of the Weak State: Leadership Imperatives for the Ramos Government. Contemporary Southeast Asia. 1994;16(1):67-32.

[13] Lim J. Detrimental Role of Biased Policies: Governance Structures and Economic Development. In: Doronila $A$, editor. Between Fires: 15 Perspectives on the Estrada Administration. Manila, Phillippines: Anvil Press; 2001.

[14] Fabella R. The Soft State, the Market, and Governance. Philippine Review of Economics. 2000;37(1):1-11.

[15] Velasco R. Philippine Democracy: Promise and Performance. In: Laothamatas $A$, editor. Democratization in Southeast and East Asia. New York, NY, USA: St. Martin's Press; 1997.

[16] Vatikiotis M. Political Change in Southeast Asia: Trimming the Banyan Tree. New York, NY, USA: Routledge; 1996.

[17] Lande C. Brief History of the Philippine Political Parties. In: Abueva J, de Guzman R, editors. Foundations and Dynamics of Filipino Government and Politics. Manila, Philippines: Bookmarks; 1969.
[18] Hollsteiner M. The Dynamics of Power in a Philippine Municipality. Quezon City, Philippines: University of the Philippines Press; 1963.

[19] Grossholtz J. Politics in the Philippines. Boston, MA, USA: Little Brown; 1964.

[20] Corpuz O. The Philippines. Englewood Cliffs, NJ, USA: Prentice-Hall; 1964.

[21] Eaton K. Restoration or Transformation? Trapos versus NGOs in the Democratization of the Philippines. Journal of Asian Studies. 2003;62(2):469-496.

[22] Manacsa R. The Formal Structures for Political Participation: The Electoral and Party Systems in the Philippines. In: Department of Political Science, editor. Politics and Governance in the Philippine Context. Quezon City, Philippines: Ateneo de Manila University Press; 1999.

[23] Magno F. Traditional and New Politics in the Philippines. In: Holmes R, editor. Philippine Government. Manila, Philippines: De La Salle University Press; 1995.

[24] Sidel J. Capital, Coercion and Crime: Bossism in the Philippines. Stanford, CA, USA: Stanford University Press; 1999.

[25] Sidel J. Beyond Patron-Client Relations: Warlordism and Local Politics in the Philippines. Kasarinlan: Philippine Journal of Third World Studies. 1989;4(3):19-30.

[26] Linz J. Totalitarian and Authoritarian Regimes. In: Greenstein F, Polsby N, editors. Handbook of Political Science, Vol. 3: Macropolitical Theory. Boston, MA, USA: Addison-Wesley; 1975.

[27] Weber M. Economy and Society: An Outline of Interpretive Sociology. Oakland, CA, USA: University of California-Berkeley Press; 1978.

[28] Hawes G. The Philippine State and the Marcos Regime: The Politics of Exports. Ithaca, NY, USA: Cornell University Press; 1987.

[29] Bautista R. Impediments to Trade Liberalization in the Philippines. London, UK: Trade Policy Research Center, 1989.

[30] Ranis G. Sharing in Development: A Programme of Employment, Equity and Growth for the Philippines. Geneva, Switzerland: International Labour Organization; 1974.

[31] Sarel M. Growth in East Asia: What we can and what we cannot infer? Washington, DC, USA: International Monetary Fund; 1996.

[32] Montes M. The Business Sector and Development Policy. In: Ishi A, editor. National Development Policies and the Business Sector in the Philippines. Tokyo, Japan: Institute of Developing Economies; 1988.

[33] Hutchcroft P. The Arroyo Imbroglio in the Philippines. Journal of Democracy. 2008;19(1):141-155.

[34] Quimpo N. The Left, Elections, and the Political Party System in the Philippines. Critical Asian Studies. 2005;37(1):3-28.

[35] Atienza M, Berja C, Cabilo Z, Baviera M. Developing a Human Security Index for the Philippines: 
An Exploratory Study in Selected Conflict Areas. Quezon City, Phillippines: United National Development Programme; 2010.

[36] Republic of the Philippines. Republic Act No. 9372: Human Security Act. Quezon City, Philippines: House of the Representatives; 2007. Available from: http://www.congress.gov.ph/download/ra_13/RA0937 2.pdf

[37] United Nations Development Programme. Human Development Report-New Dimensions of Human Security. New York, NY, USA: Oxford University Press; 1994.

[38] United Nations General Assembly. Fifty-ninth Session: Note by the Secretary General on 2 December 2004. Available from: http://www1.umn.edu/ humanrts/instree/report.pdf.

[39] International Federation for Human Rights. Terrorism and Human Rights in the Philippines Fighting Terror or Terrorizing. Paris, France: FIDH; 2008.

[40] Gomez O. Introducing the "Human" into Philippine Security Discourses: Convergence or Dialogue? Philippine Journal of Third World Studies. 2011;26(12):153-182.

[41] Lyew B. An Examination of the Philippines' Anti-terror Law. Pacific Rim Law and Policy Journal. 2010;19(1):187-216.

[42] Human Rights Council. Fourteenth Session: Report of the Special Rapporteur on Extrajudicial, Summary or Arbitrary Executions; 2010. Available from: http://www2.ohchr.org/english/bodies/hrcouncil/ docs/14session/A.HRC.14.24.Add6.pdf.

[43] Human Rights Watch. Philippines. New Terrorism Law Puts Rights at Risk; 2007. Available from: http://www.hrw.org/news/2007/07/15/philippinesnew-terrorism-law-puts-rights-risk.

[44] Federation of Malaysia. National Security Council. Available from: http://www.mkn.gov.my/ $\mathrm{mkn} /$ default/article_m.php?mod=4\&fokus $=14$.

[45] Crump T. Asia-Pacific: A History of Empire and Conflict. London, UK: Hambledon Continuum; 2007.

[46] Nathan KS. Malaysia: Reinventing the Nation. In: Alagappa $M$, editor. Asian Security Practice: Material and Ideational Influences. Standord, CA, USA: Stanford University Press; 1998.

[47] Azizuddin MS. Balancing Freedom of Speech and National Security in Malaysia. Asian Politics and Policy. 2013;5(4):585-607.

[48] Humphreys A. Malaysia's Post-9/11 Security Strategy: Winning Hearts and Minds or Legitimising the Political Status Quo? Kajian Malaysia. 2010;28(1):21-52.

[49] Hussein SA. Muslim Politics and the Discourse of Democracy. In: Khoo BT, Wah F, editors. Democracy in Malaysia: Discourses and Practices. Surrey, UK: Curzon Press; 2010.

[50] Sato Y. Perceptions of Transnational Security Threats in Malaysia and Singapore: Windows of Cooperative Opportunities for the United States. In: Smith $E$, editor. Issues for Engagement: Asian Perspectives on Transnational Security Challenges.
Honolulu, HI, USA: Asia-Pacific Center for Security Studies; 2010.

[51] Othman N. Globalization, Islamic Resurgence, and State Autonomy: The Response of the Malaysian State to Islamic Globalization. In: Nelson J, Meerman J, Embong AR, editors. Globalization and National Autonomy: The Experience of Malaysia. Singapore: Institute of Southeast Asian Studies; 2008.

[52] Beeson M, Bellamy A. Securing Southeast Asia: The Politics of Security Sector Reform. New York, NY, USA: Routledge; 2008.

[53] Gomez ET. Introduction: Resistance to Change -Malay Politics in Malaysia. In: Gomez ET, editor. Politics in Malaysia: The Malay Dimension. New York, NY, USA: Routledge; 2007.

[54] Khoo BT, Wah F, editors. Democracy in Malaysia: Discourses and Practices, Surrey, UK: Curzon Press; 2002.

[55] Hilley J. Malaysia: Mahathirism, Hegemony and the New Opposition. New York, NY, USA: St. Martin's Press; 2001.

[56] Embong AR. Developmentalist State in Malaysia: Its Origins, Nature, and Contemporary Transformation. In: Nelson J, Meerman J, Embong AR, editors. Globalization and National Autonomy: The Experience of Malaysia. Singapore: Institute of Southeast Asian Studies; 2008.

[57] Nelson J. Introduction. In: Nelson J, Meerman J, Embong AR, editors. Globalization and National Autonomy: The Experience of Malaysia. Singapore: Institute of Southeast Asian Studies; 2008.

[58] Case W. Testing Malaysia's Pseudo-Democracy. In: Gomez ET, editor. The State of Malaysia: Ethnicity, Equity and Reform. New York, NY, USA: Routledge Curzon; 2004.

[59] Lee J. Malaysian Dilemma: The Enduring Cancer of Affirmative Action. Foreign Policy Analysis. 2011;(6):1-20.

[60] Federation of Malaysia. 1936 Constitution of Malaysia. Available from: http://www.jac.gov.my/ images/stories/akta/federalconstitution.pdf

[61] Barisan Nasional. Official Website. Available from: http://www.barisannasional.org.my/en/welcome.

[62] Chen O. The Influences of the Internalization of International Structure to Malaysia's National Security. Asian Social Science. 2012;8(3):151-155.

[63] Azizuddin MS. A Comparative Analysis of Asian Values and Islam Hadhari in Malaysia. Jurnal Kemanusiaan. 2010;(15):1-22.

[64] Downs A. An Economic Theory of Democracy. New York, NY, USA: Harper \& Row; 1957.

[65] Apter D. The Politics of Modernization. Chicago, IL, USA: University of Chicago Press; 1965.

[66] Mohamad M. Legal Coercion, Legal Meaning and UMNO's Legitimacy. In: Gomez ET, editor. Politics in Malaysia: The Malay Dimension. New York, NY, USA: Routledge; 2007.

[67] Derichs C. Political Crisis and Reform in Malaysia' in Malaysia. In: Gomez ET, editor. The State 
of Malaysia: Ethnicity, Equity and Reform. New York, NY, USA: Routledge Curzon; 2004.

[68] Welsh B. Real Change? Elections in the Reformasi Era. In: Gomez ET, editor. The State of Malaysia: Ethnicity, Equity and Reform. New York, NY, USA: Routledge Curzon; 2004.

[69] Hamayotsu K. Islamisation, Patronage and Political Ascendancy: The Politics and Business of Islam in Malaysia. In: Gomez ET, editor. The State of Malaysia: Ethnicity, Equity and Reform. New York, NY, USA: Routledge Curzon; 2004.

[70] Khan J. Islam, Modernity, and the Popular in Malaysia. In: Hooker V, Othman N, editors. Malaysia: Islam, Society and Politics. Singapore: Institute of Southeast Asian Studies; 2003.

[71] Milner A. How Traditional is the Malaysian Monarchy. In: Hooker V, Othman N, editors. Malaysia: Islam, Society and Politics. Singapore: Institute of Southeast Asian Studies; 2003.

[72] Nelson J. Conclusions. In: Nelson J, Meerman J, Embong AR, editors. Globalization and National Autonomy: The Experience of Malaysia. Singapore: Institute of Southeast Asian Studies; 2008.

[73] Syed AT, Chuan NT. Abdullah Ahmad Badawi. Subang Jaya, Malaysia: Pelanduk Publication; 2005.

[74] Chong T. The Emerging Politics of Islam Hadhari. In: Swee-Hock S, Kesavapany K, editors. Malaysia: Recent Trends and Challenges. Singapore: Institute of Southeast Asian Studies; 2006.

[75] Lee P. The Look East Policy, the Asian Crisis, and State Autonomy. In: Nelson J, Meerman J, Embong AR, editors. Globalization and National Autonomy: The Experience of Malaysia. Singapore: Institute of Southeast Asian Studies; 2008.

[76] Noor F. The Localization of Islamist Discourse in the Tasfir of Tuan Guru Nik Aziz Nik Mat, Murshid'ul Am of PAS. In: Hooker $\mathrm{V}$, Othman $\mathrm{N}$, editors. Malaysia: Islam, Society and Politics. Singapore: Institute of Southeast Asian Studies; 2003.

[77] Hooker V. Malaysia: Still Islam and Politics but now Enmeshed in a Global Web. In: Hooker V, Othman N, editors. Malaysia: Islam, Society and Politics. Singapore: Institute of Southeast Asian Studies; 2003.

[78] Gomez ET, Jomo KS. Malaysia's Political Economy: Politics, Patronage and Profits. Cambridge,
UK: Cambridge University Press; 1997.

[79] Human Rights Watch. Malaysia: Protect Freedom of Belief for Sky Kingdom; 2005. Available from: http://www.hrw.org/news/2005/07/20/malaysiaprotect-freedom-belief-sky-kingdom.

[80] BBC. Malaysian Teapot Worship-The Ayah Pin Cult; 2005. Available from: http://news.bbc.co.uk/ dna/placelancashire/plain/A38083476.

[81] The Strait Times. Backed by Muslims, KL takes on extremists; 2004. Available from: http://eresources. nlb.gov.sg/newspapers/Digitised/Article/straitstimes2004 0406-1.2.36.8.1.aspx.

[82] Abbott J. The Internet, Reformasi and Democratisation in Malaysia. In: Gomez ET, editor. The State of Malaysia: Ethnicity, Equity and Reform. New York, NY, USA: Routledge Curzon; 2004.

[83] Federation of Malaysia. Internal Security Act; 1960. Available from: http://www.agc.gov.my/ Akta/Vol.\%202/Act2082.pdf.

[84] Federation of Malaysia. Sedition Act; 1948. Available from: http://www.agc.gov.my/Akta/Vol. \%201/Act\%2015.pdf.

[85] Lopez C. Globalisation, State and G/Local Human Rights Actors: Contestations between Institutions and Civil Society. In: Gomez ET, editor. Politics in Malaysia: The Malay Dimension. New York, NY, USA: Routledge; 2007.

[86] Saravanamuttu J. The Eve of the 1999 General Election: From the NEP to Reformasi. In: Wah F, Saravanamuttu J, editors. New Politics in Malaysia. Singapore: Institute of Southeast Asian Studies; 2003.

[87] Human Rights Watch. In the Name of Security: Counterterrorism and Human Rights Abuses Under Malaysia's Internal Security Act; 2004. Available from: http://www.hrw.org/sites/default/files/reports/malaysia0 504.pdf.

[88] Flaherty M, Fritz N. Unjust Order: Malaysia's Internal Security Act. Fordham International Law Journal. 2002;26(5):1345-1437.

[89] Federation of Malaysia. Security Offences (Special Measures) Act; 2012. Available from: http://www.federalgazette.agc.gov.my/outputaktap/20 120622_747_BI_Act\%20747\%20BI.pdf.

[90] Spiegel M. Smoke and Mirrors: Malaysia's "New" Internal Security Act. Asia Pacific Bulletin. 2012;167:1-3. 